\title{
Robotic Rectal Cancer Surgery with the da Vinci Xi System: First 100 Cases
}

\author{
da Vinci Xi Sistemi ile Robotik Rektum Kanseri Cerrahisi: Illk 100 Olgu

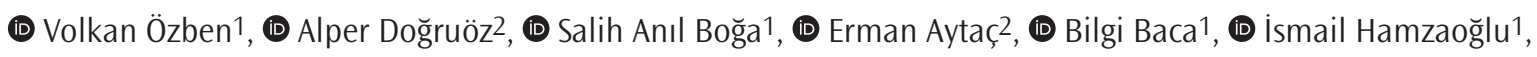 \\ (D) Tayfun Karahasanoğlu1
}

${ }^{1}$ Acıbadem Mehmet Ali Aydınlar University Faculty of Medicine, Department of General Surgery, İstanbul, Turkey

${ }^{2}$ Acıbadem Mehmet Ali Aydınlar University Faculty of Medicine, İstanbul, Turkey

\begin{abstract}
Introduction: The da Vinci $\mathrm{Xi}$ system, the latest model of the robotic technology, is proposed to enable multiquadrant abdominal surgery to be performed in a fully robotic approach without the need for a laparoscopic assistance, robot re-docking or re-positioning of the trocars. However, the literature has limited data on this topic. In this study, we aimed to evaluate the feasibility of the $\mathrm{Xi}$ robot use in rectal cancer surgery, a multiquadrant surgical procedure.
\end{abstract}

Methods: Patients undergoing robotic mezorectal excision for rectal adenocarcinoma using the da Vinci Xi system between December 2014 and June 2017 were included in this study. Data were collected prospectively and analyzed retrospectively. Demographic data, perioperative clinical findings, histopathologic data and postoperative 30-day outcomes were analyzed.

Results: One hundred patients were included in this study. There were 57 male and 43 female patients with a mean age of $61.4 \pm 12.3$ years. Low anterior resection and abdominoperineal recetion were performed in 90 and 10 patients, respectively. In all the operations, the abdominal and pelvic stages of the procedure were completed robotically without a need for dual docking or trocar re-positioning. The mean operative time was $328.4 \pm 105.8 \mathrm{~min}$ and blood loss was $131.7 \pm 170.3$ $\mathrm{mL}$. Intraoperative complication occurred in 2 patients (2\%). Two procedures were converted to open surgery (2\%). The mean number of harvested lymph nodes was $25.3 \pm 12.0$. All the surgical margins were clear except for four patients (4\%). The rate of incomplete mesorectal fascia was 3.2\%. The mean length of hospital stay was $6.6 \pm 3.6$ days and the overall postoperative morbidity rate was $25 \%$.

Conclusion: The da Vinci $\mathrm{Xi}$ model enables rectal cancer operations to be performed in a fully robotic fashion. This feature of the robot helps surgeon to benefit optimally from the advantages robotic surgery in all stages of the procedure.

Keywords: da Vinci Xi system, rectal cancer, robotik mesorectal excision

\section{öZ}

Amaç: Robot teknolojisinin en güncel modeli olan da Vinci Xi sisteminin multikadran karın ameliyatlarını laparoskopi yardımı olmadan, robotu tekrar konușlandırma veya trokar pozisyonunda değişiklik gerektirmeden tamamen robot ile yapılmasını mümkün kıldığı öne sürülmektedir. Ancak bu konu üzerinde literatür verisi sınırlıdır. Bu çalıșmada multikadran bir cerrahi olan rektum kanseri ameliyatında Xi robot kullanımının uygulanabilirliğini değerlendirmeyi amaçladık.

Yöntemler: Çalışmaya Aralık 2014 ile Haziran 2017 tarihleri arasında rektum adenokanseri tanısı ile da Vinci Xi sistemi kullanılarak robotik mezorektal eksizyon ameliyatı yapılan hastalar alındı. Veriler prospektif kaydedildi ve retrospektif olarak incelendi. Hastaların demografik bilgileri, intraoperatif bulgular, histopatolojik veriler ve postoperatif 30 gün sonuçları değerlendirildi.

Bulgular: Çalıșmaya toplam 100 hasta dahil edildi. Hastaların 57'si erkek, 43'i kadın, ortalama yaş 61,4 $\pm 12,3$ yıl idi. Doksan hastaya așağı anteriyor rezeksiyon ve 10 hastaya abdominoperineal rezeksiyon uygulandı. Tüm ameliyatlarda karın ve pelvis aşamaları robotun ikinci defa konușlandırılmasına gerek duyulmadan ve trokarların yeri değiştirilmeden tamamlandı. Ortalama ameliyat süresi $328,4 \pm 105,8$ dk ve kanama miktarı 131,7 $\pm 170,3 \mathrm{~mL}$ idi. Iki hastada intraoperatif komplikasyon geliști (\%2). Iki hastada açık cerrahiye geçildi (\%2). Çıkarılan ortalama lenf nodu sayısı 25,3 $\pm 12,0$ idi. Radyal sınır pozitifliği saptanan 4 hasta (\%) dışındaki tüm hastalarda cerrahi sınırlar temiz bulundu. Inkomplet mezorektal fasya bütünlüğü oranı \%3,2 idi. Ortalama hastanede yatış süresi $6,6 \pm 3,6$ gün ve postoperatif toplam morbidite oranı \%25 idi.

Sonuç: da Vinci Xi modeli rektum kanseri ameliyatlarının tamamen robotik yapılmasını mümkün kılmaktadır. Robotun bu özelliği cerrahın ameliyatın tüm aşamalarında robotik cerrahinin avantajlarından optimal bir şekilde faydalanmasını sağlamaktadır.

Anahtar Kelimeler: da Vinci Xi sistemi, rektum kanseri, robotik mezorektal eksizyon
Address for Correspondence/Yazıșma Adresi: Bilgi Baca, Acıbadem Mehmet Ali Aydınlar University Faculty of Medicine, Department of General Surgery, İstanbul, Turkey

Phone: +90 5327340265 E-mail: bilgibaca@hotmail.com ORCID ID: orcid.org/0000-0003-1704-2533

Cite this article as/Atıf: Özben V, Doğruöz A, Boğa SA, Aytaç E, Baca B, Hamzaoğlu i, Karahasahoğlu T. Robotic Rectal Cancer Surgery with the da Vinci Xi System: First 100 Cases. İstanbul Med J 2019; 20(1): 1-7.
Received/Geliş Tarihi: 25.08.2017 Accepted/Kabul Tarihi: 18.07.2018

(c) Copyright 2019 by the Istanbul Training and Research Hospital/istanbul Medical Journal published by Galenos Publishing House.

(C) Telif Hakkı 2019 Istanbul Ĕgitim ve Araștırma Hastanesi/Istanbul Tıp Dergisi, Galenos Yayınevi tarafından basılmıștır. 


\section{Introduction}

In the last 30 years, significant advances have been made in the treatment of rectal cancer with the use of neoadjuvant therapies and identification of total mesorectal excision technique $(1,2)$. In the field of surgery, demonstration of the advantages of laparoscopic surgery compared to open surgery in terms of early postoperative results $(3,4)$ led to the spread of minimally invasive surgery. However, the technical difficulties experienced due to the use of flat and rigid instruments in a narrow and deep anatomical area such as the pelvis (5), and high rates of switching to open surgery and peripheral surgical margin positivity $(6,7)$ have made the oncological effectiveness of mesorectal excision with classical laparoscopy a matter of discussion.

In addition to the advantages of minimally invasive surgery, robotic surgery has eliminated the disadvantages of classical laparoscopy thanks to better mobility with angled instruments in the narrow space, threedimensional high-resolution imaging and stable tissue traction (8). In the following years, the increase in interest in robotic surgery brought about technological developments in robotic systems. Rectal cancer surgery is a multiquadrant surgery involving mesorectal dissection in the pelvis and mobilization of the left colon in the abdomen. The fact that the previous robot model, da Vinci Si (Intuitive Surgical Inc., Sunnyvale, CA, USA), allowed a single quadrant surgery in the abdomen, led the surgeons to use different techniques to mobilize the left colon (911). It is reported that the da Vinci Xi model, which is currently the most up-to-date system, has eliminated this problem with its multiquadrant access feature. However, the experience on this subject was limited by the data reported from a small number of patients (12-15).

In our own practice, we use the da Vinci Xi system routinely as of November 2014. In this study, we aimed to present the technical details and the perioperative clinical results of the robotic mesorectal excision surgeries performed since this date.

\section{Methods}

The study was approved by the Ethics Committee of Acıbadem Mehmet Ali Aydınlar University Hospital with the decision number 2017-12/7. Patients who underwent robotic mesorectal excision due to rectum adenocarcinoma between December 2014 and May 2017 in the General Surgery Departments of Acıbadem Atakent and Maslak Hospitals were included in the study. Patients with synchronous colon tumors were excluded from the study. Informed consent was obtained from all patients included in the study and their data were used. Demographic and preoperative clinical data, intraoperative findings, histopathological data, and results of postoperative 30-day outcome were entered into the colorectal cancer database prospectively (16) and the data were evaluated retrospectively. The docking time was determined as the time between positioning of the robot and connection of the robotic arms to the trocars. The total operative time was determined as the time between the first skin incision and the closure of the incision. The conversion was defined as the completion of any stage of the surgery with an open or classical laparoscopic approach, with the exception of the abdominal incision made for removal of the specimen.

Following rectal cancer diagnosis with endoscopic and histopathological examination, clinical staging of the tumor was performed with the help of computerized tomography of the thorax and abdomen, endorectal ultrasonography and/or magnetic resonance imaging. Neoadjuvant chemotherapy/radiotherapy was administered to the patients who were diagnosed as having T3-4 or N + stage tumors that were located under the pelvic peritoneal reflection. The patients were treated with Na-phosphate soda and enema one day before the surgery and venous thrombosis prophylaxis 12 hours before the operation. Antibiotic prophylaxis was applied during general anesthesia induction and then nasogastric tube and urinary catheter were placed.

\section{Robotic Mesorectal Excision Technique}

The patient was placed in a modified lithotomy position. A Veress needle was inserted through a supraumbilical incision and pneumoperitoneum was established using $\mathrm{CO}_{2}$ at a pressure of $12 \mathrm{mmHg}$. A 30-degree robot camera was advanced from the $8-\mathrm{mm}$ robot trocar placed in this area, and three other 8-mm robots and 5-mm assistant trocars were placed under direct vision (Figure 1). The operating table was positioned to Trendelenburg with 30 degrees right side tilt, and the omentum was retracted upwards over the transverse colon and the small intestine was retracted to the right upper quadrant of the abdomen. The robot was on the left side of the patient and the assistant was on the right side. After placing a camera in Arm 2, the robot system was targeted to the left inguinal area and the robotic arms were mounted on the trocars.

The surgery was performed by medial to lateral dissection technique. Visceral peritoneum was opened with scissors after the sigmoid colon was mobilized anteriorly and laterally with tip-up grasper. The inferior mesenteric artery (IMA) was ligated $1 \mathrm{~cm}$ distal to the origin by using Hem-o-lok clips (Teleflex, Morrisville, NC, USA) and divided. The inferior mesenteric vein was ligated and divided at the lower limit of the pancreas (Figures 2, 3). Omental bursa was reached through the plane between the anterior surface of the pancreas and the mesocolon. Then, the Toldt fascia was dissected through the embryological avascular region, and medial to lateral mesocholic dissection was completed with preserving the left ureter and gonadal veins. The lateral peritoneal ligaments of the descending colon and splenic flexure were dissected. After the descending colon was mobilized, posterior mesorectum was dissected by protecting the autonomic nerve plexus through the plane between the presacral fascia and mesorectal fascia at the level of promontorium. After posterior mobilization was achieved, the total mesorectal excision procedure was completed by reaching to the pelvic floor through both lateral and then anterior planes (Figure 4). Partial mesorectal excision was performed in case of tumors located in the upper rectum. The trocar in the lower right quadrant was replaced by a $12 \mathrm{~mm}$ robotic or laparoscopic trocar, and the rectum was excised by the robotic stapler (EndoWrist $45 \mathrm{~mm}$ stapler, Intuitive Surgical, Inc.) or laparoscopic stapler (Echelon Flex ${ }^{\mathrm{TM}} 60 \mathrm{~mm}$ stapler, Ethicon, Cincinnati, $\mathrm{OH}$, USA) advanced through this trocar. Then, a suprapubic incision was made and the wound protector/retractor (Alexis ${ }^{\mathrm{TM}}$ ) was inserted into the incision. Specimen was taken out of the abdomen from this incision (Figure 5). After the proximal colon was cut, the anvil of the circular stapler was inserted in the proximal end of the colon with purse string suture and left in the abdomen, and the suprapubic incision was sutured. Colorectal or coloanal anastomosis was performed with circular stapler advanced from the anus. In some patients, vascularization of the descending colon was evaluated with the FireFly ${ }^{\top \mathrm{M}}$ camera of the 


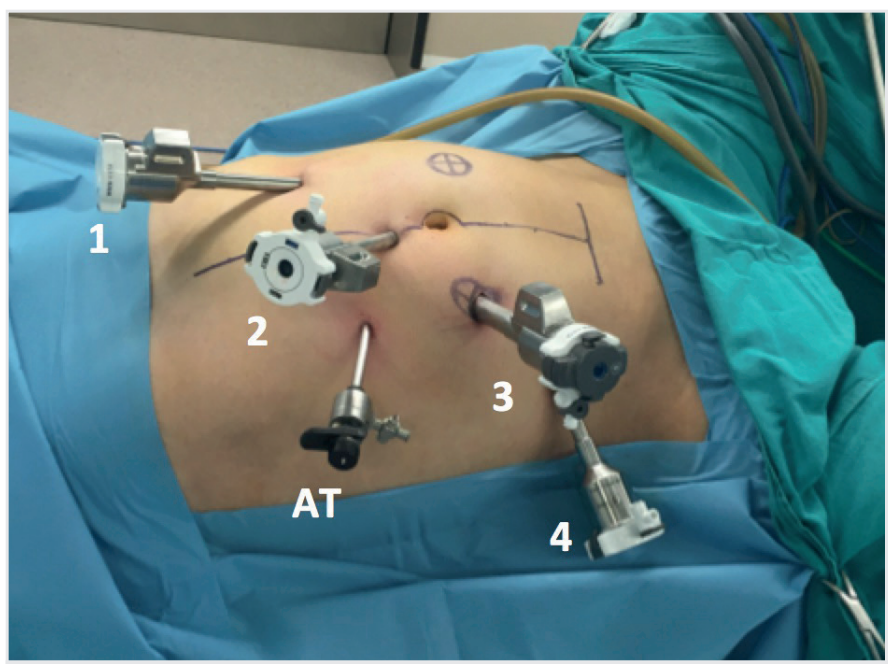

Figure 1. Trocar position in robotic rectal cancer surgery. Camera was connected to Arm 2, bipolar forceps to Arm 1, monopolar scissors to Arm 3 and tip-up grasper to Arm 4

\section{AT: Assistant trocar}

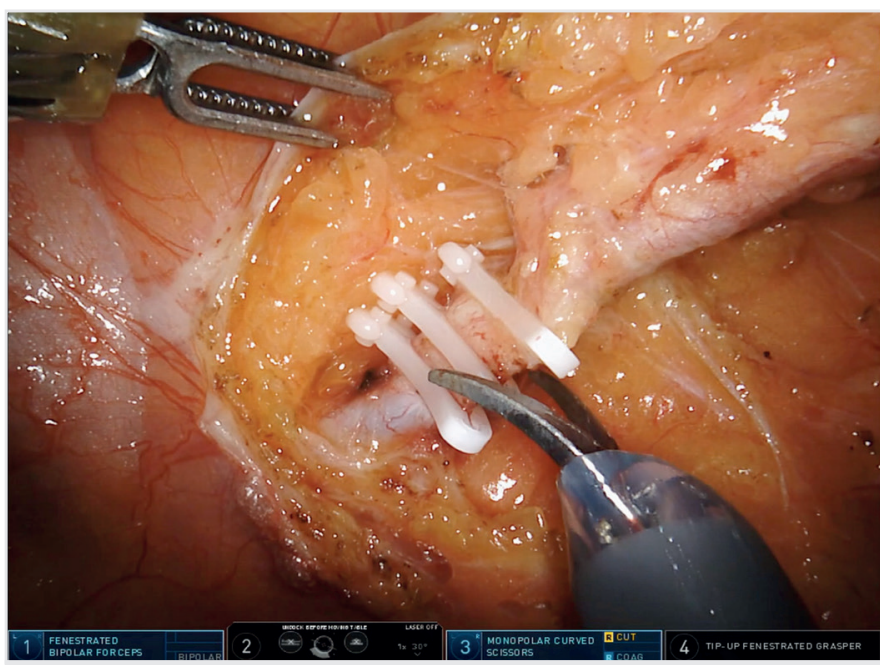

Figure 2. Ligation and division of the inferior mesenteric artery

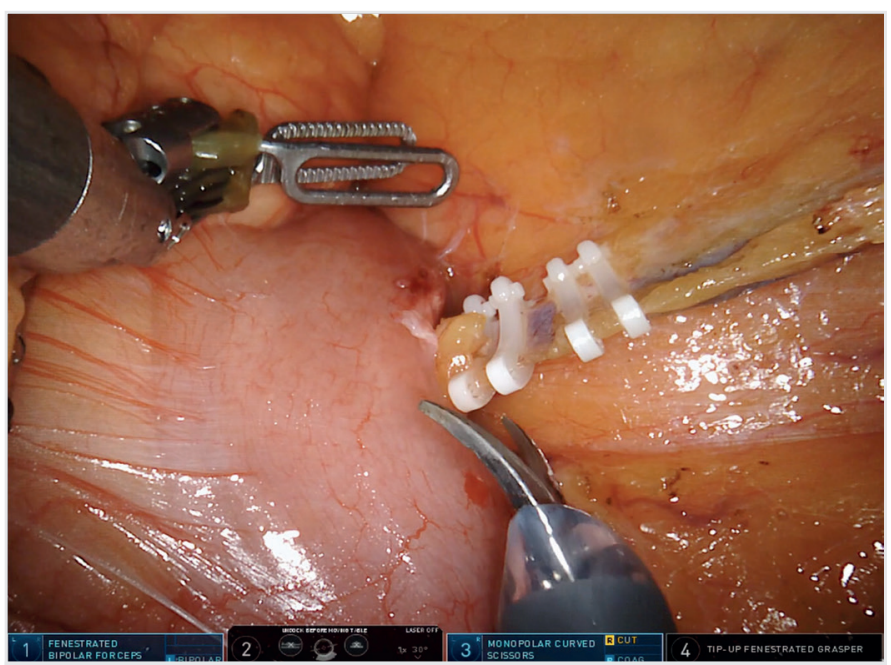

Figure 3. Ligation and division of the inferior mesenteric vein robot following intravenous indocyanine green $(2.5 \mathrm{mg} / \mathrm{mL})$ prior to anastomosis. Anastomotic leakage control was performed by air test and a silicone drain was placed in the pelvis. Then fascia and skin incisions of $12 \mathrm{~mm}$ trocar location were sutured. The operations were finalized following performing a diverting loop ileostomy.

In cases where intersphincteric resection was required, perineal dissection was performed after the rectal dissection was performed to the intersphincteric plane with robot in the abdominal stage. Total mesorectal excision was completed by entering the intersphincteric plane with an incision at the dentate line. After the specimen was removed from the anus, a manual coloanal anastomosis was performed. In patients who needed abdominoperineal resection, the pelvic stage was performed with extralevator approach following completion of the abdominal stage with the robot.

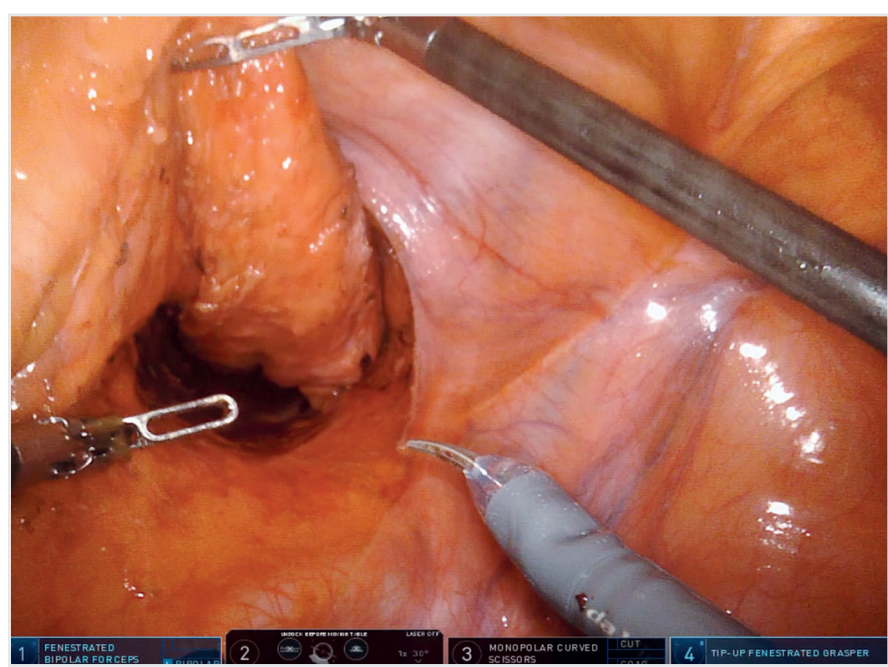

Figure 4. Completion of total mesorectal excision

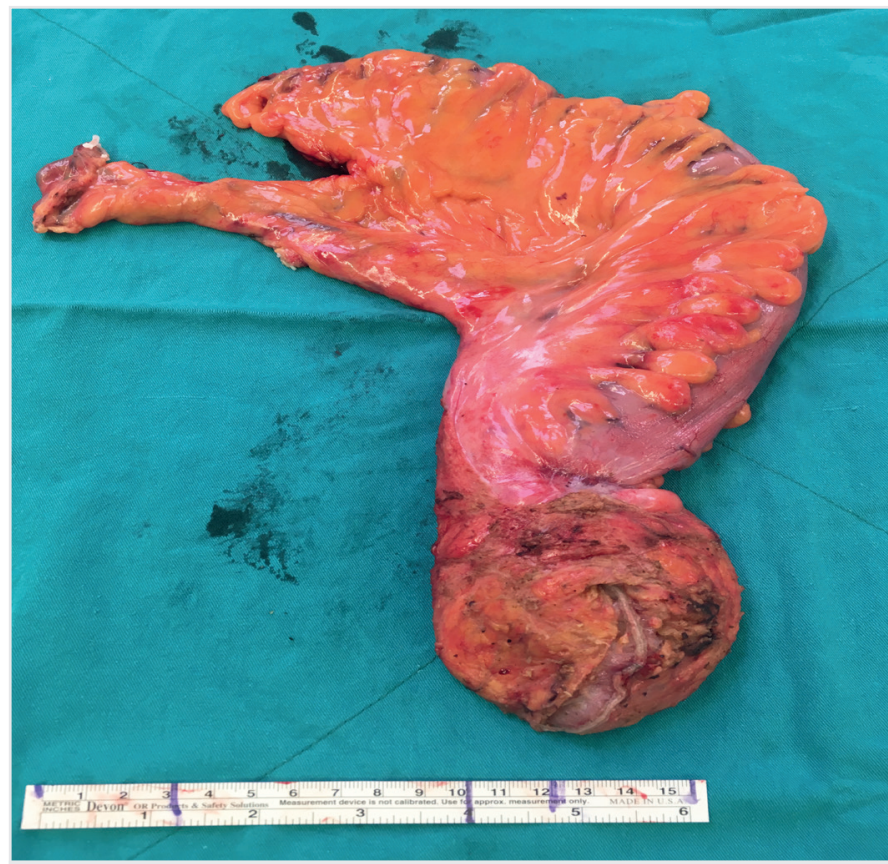

Figure 5. Total mesorectal excision specimen 
Postoperative pain control was achieved with intravenous narcotic drugs. The nasogastric catheter was removed immediately after the operation and the urinary catheter was removed on the first postoperative day. Patients were discharged after adequate pain control and oral feeding.

\section{Statistical Analysis}

Statistical analysis of the data was performed by SPSS 20.0 (SPSS Inc., Chicago, IL, USA). Categorical data were expressed as frequency and percentage $(n, \%)$ and continuous variables as mean \pm standard deviation.

\section{Results}

A total of 100 patients were included in the study. Fifty-seven of all patients (57\%) were male and 43 were female. Mean age was $61.4 \pm 12.3$ years and body mass index was $27.3 \pm 3.6 \mathrm{~kg} / \mathrm{m}^{2}$. Demographic data and preoperative clinical information are presented in Table 1. In our series, the most common tumor was distal rectal tumor (44\%), followed by proximal (38\%) and middle rectal (17\%) tumors. The operations, intraoperative data and follow-up findings of the first postoperative 30day are presented in Table 2. Ninety patients underwent low anterior resection and 10 patients underwent abdominoperineal resection. Intersphincteric resection was performed in 15 patients who had undergone low anterior resection. In all operations, the abdominal and pelvic stages were completed without the need for robot re-docking or re-positioning of the trocars. The mean robot docking time was $4.9 \pm 1.5$ minutes, mean operative time was $328.4 \pm 105.8$ minutes and blood loss was $131.7 \pm 170.3 \mathrm{~mL}$. Intraoperative complication occurred in two patients (2\%). These complications were prostatic urethral injury and bleeding after removal of the clip placed on IMA. Urethral injury was repaired intraoperatively. The other patient who developed hemorrhage underwent open surgery. Open surgery was performed in two patients

\begin{tabular}{|c|c|}
\hline \multicolumn{2}{|l|}{ Gender } \\
\hline Male & $57(57 \%)$ \\
\hline Female & $43(43 \%)$ \\
\hline Age, years & $61.4 \pm 12.3$ \\
\hline $\mathrm{BMI}, \mathrm{kg} / \mathrm{m}^{2}$ & $27.3 \pm 3.6$ \\
\hline \multicolumn{2}{|l|}{ ASA score } \\
\hline 1 & $27(27 \%)$ \\
\hline II & $62(62 \%)$ \\
\hline III & $10(10 \%)$ \\
\hline IV & $1(1 \%)$ \\
\hline Previous abdominal surgery & $19(19 \%)$ \\
\hline \multicolumn{2}{|l|}{ Tumor location } \\
\hline Proximal rectum & $38(38 \%)$ \\
\hline Middle rectum & $17(17 \%)$ \\
\hline Distal rectum & $44(44 \%)$ \\
\hline Proximal + distal rectum & $1(1 \%)$ \\
\hline Neoadjuvant chemotherapy/ radiotherapy & $46(46 \%)$ \\
\hline
\end{tabular}

(2\%), one because of the inability to continue dissection due to severe tumoral adhesion in the pelvis and the other due to bleeding from the IMA (following removal of the clip). The mean time to first defecation and oral feeding was $2.9 \pm 1.6$ days and $3.3 \pm 1.7$ days, respectively and mean hospital stay was $6.6 \pm 3.6$ days.

Twenty five patients (25\%) had morbidity within the first 30 days postoperatively (Table 2). Anastomotic leakage occurred in three patients (3\%); this complication was controlled by diverting ileostomy in two patients and conservative treatment in the other one. All of 12 patients who developed ileus had paralytic origin and it regressed with conservative treatment. Percutaneous drainage was performed in one patient who developed intraabdominal abscess and diverting ileostomy was performed in one patient with rectovaginal fistula. There was no mortality.

Histopathological data and oncologic results are presented in Table 3. The mean number of harvested lymph nodes was $25.3 \pm 12.0$. Lymph node metastasis was detected in 31 patients and the mean number of metastatic lymph nodes was 1.3 3 3.0. All the surgical margins were clear, except for radial margin positivity in four patients (4\%). In 61 of 63 patients who underwent total mesorectal excision, the integrity of the mesorectal fascia was complete or near complete (96.8\%).

Table 2. Intraoperative and postoperative findings

Surgery

Low anterior resection

$90(90 \%)$

Abdominoperineal resection

$10(10 \%)$

\section{Mesorectal excision}

Total

$63(63 \%)$

Partial

$37(37 \%)$

Robot docking time, minimum

$4.9 \pm 1.5$

Operative time, minimum

$328.4 \pm 105.8$

Bleeding, $\mathrm{mL}$

$131.7 \pm 170.3$

Intraoperative complication

$2(2 \%)$

Conversion

$2(2 \%)$

Time to first flatus, days

$2.0 \pm 1.0$

Time to first defecation, days

$2.9 \pm 1.6$

Time to first oral feeding, days

$3.3 \pm 1.7$

Length of hospital, days

$6.6 \pm 3.6$

\section{0-day morbidity}

lleus

$12(12 \%)$

Wound infection

$5(5 \%)$

Anastomosis leak

$3(3 \%)$

Intraabdominal abscess

$1(1 \%)$

Rectovaginal fistula

$1(1 \%)$

Pulmonary embolism

$1(1 \%)$

Atelectasis

$1(1 \%)$

Urinary tract infection

$1(1 \%)$

Mortality

$0(0 \%)$

Data are presented as number (\%) or mean \pm standard deviation 


\section{Table 3. Histopathological data}

Tumor diameter, $\mathrm{cm}$

$3.7 \pm 2.2$

Number of lymph nodes

$25.3 \pm 12.0$

Number of metastatic lymph nodes

$1.3 \pm 3.0$

pT

$\mathrm{T}_{0}$

$\mathrm{T}_{1}$

$\mathrm{T}_{2}$

$\mathrm{T}_{3}$

$\mathrm{T}_{4}$

$\mathrm{pN}$

$\mathrm{N}_{0}$

$\mathrm{N}_{1}$

$\mathrm{N}_{2}$

\section{pTNM staging}

0

।

II

III

IV

Proximal surgical margin, $\mathrm{cm}$

Distal surgical margin, $\mathrm{cm}$

Radial surgical margin, cm

Surgical margin positivity

The integrity of the mesorectal fascia ${ }^{a}$

Complete

$38(60.3 \%)$

Near-complete

$23(36.5 \%$

Incomplete

$2(3.2 \%)$

pTNM: pathological tumor-node-metastasis

${ }^{a}$ Mesorectal fascia integrity was evaluated in 63 patients who underwent total mesorectal excision. Data are presented as number (\%) or mean \pm standard deviation

\section{Discussion}

The results of our study support the feasibility of mesorectal excision surgery in the rectum cancer surgery with a fully robotic approach with the help of the da Vinci Xi system. Compared to the da Vinci Si system, features such as thinner and longer arm structure of the Xi system, ergonomic trocar alignment, the ability to connect the camera to the desired trocar, automatic targeting of the robot arms and patient clearance allow the surgery to be performed from the splenic flexure to the pelvic floor with single robot docking.

The use of robots in colorectal surgery has increased especially in rectal surgery, which is performed in a narrow area, due to the visibility and movement area provided by the system. However, the most important disadvantage of the Si system is that it only allows working at a single quadrant in the abdomen (17), thus there is need for dual docking in rectal surgery that involves the abdominal and pelvic stages. As this increases both the operative time and the workload, it caused surgeons to prefer hybrid laparoscopic-robotic technique $(9,10,17-20)$. In this technique, vascular ligation and mobilization of the left colon are completed by classical laparoscopy, and the robot is used only for pelvic dissection. Surgeons who do not prefer hybrid techniques have described different techniques including repositioning to robotic arms (21-24) or modification of trocar sites (23). In the period when we used the Si system, we docked the robot twice and used a total of 7 trocars. Later on, we were able to complete the operation with a fully robotic approach by repositioning the trocars, however, crossing of the robotic arms in the extracorporeal area made the operation very difficult. This situation explains why the console time is longer in the surgeries performed with the Si system as emphasized in a previous study comparing both robotic systems (12).

In the literature, there are 3 studies comparing Vinci Xi and Si system in rectal cancer surgery. In a study in which Protyniak et al. (13) compared 44 patients in Si robot group and 26 patients in Xi robot group who underwent sigmoidectomy and anterior resection surgeries, the operative time (219 vs 224 minimum), intraoperative bleeding (170 vs. $188 \mathrm{~mL}$ ), conversion rates (3.8\% vs 11.4\%), length of hospital stay (5.7 vs 6 days) and total complication rates (26.9\% vs $22.7 \%$ ) were not significantly different. In another study comparing two robots in a total of 20 patients, Morelli et al. (15) stated that the operative time (257 vs 353 min) and length of hospital stay (6.3 vs 8.7 days) were shorter with the $\mathrm{Xi}$ system, however, there were no difference in terms of conversion and morbidity. Finally, in a study of 53 patients previously conducted in our clinic (12), we found that console time was shorter in the Xi group (265 vs. $317 \mathrm{~min}$ ), but the amount of bleeding (141 vs $181 \mathrm{~mL}$ ), conversion (3.6\% vs $4.0 \%$ ), length of hospital stay (6.2 vs 5.1 days) and postoperative complication rates $(14.3 \%$ vs $12 \%$ ) were not significantly different. The common result highlighted in these three studies is that surgeries can be completed with a fully robotic approach with the Xi system without the use of laparoscopy and without requiring the robot to be dual docked. In the present study including 100 patients, mean operative time (328 minutes), intraoperative bleeding $(132 \mathrm{~mL})$, conversion rate $(2 \%)$, length of hospital stay ( 6.6 days) and total morbidity rate $(25 \%)$ were consistent with the literature. The abdominal and pelvic stages of the operation were completed with a fully robotic approach in all cases.

One of the important stages of rectal cancer surgery is the excision of the rectum. The wide mobility of the robotic stapler and the ability of angulation up to 90 degrees offer significant advantages to the surgeon at this stage, especially in patients with a narrow pelvis (25). Robotic stapler is integrated in the Xi model in our country and is not available in Si model. We have been using robotic stapler routinely since November 2015. In addition, the evaluation of intestinal vascularization with the indocyanine green and the robot's FireFly ${ }^{\mathrm{TM}}$ camera vision is an increasingly common practice for the safety of the anastomosis (26). The FireFly ${ }^{\mathrm{TM}}$ camera feature is also available in the Xi system and requires an additional update for use in the Si system. The reason why the indocyanine green-FireFly ${ }^{\mathrm{TM}}$ camera system was not used routinely in the present study is the continuation of a randomized study in our clinic.

The use of new technologies in cancer surgeries leads to suspicion whether resection is sufficient oncologically. It is known that the 
number of lymph nodes harvested is directly related to the prognosis of the disease. The mean number of lymph nodes harvested in our series was 25.3 and this was higher than the number of lymph nodes reported in other large series (11.7-15.0) on robotic rectal cancer surgery (27-29). Surgical margin positivity was $4 \%$ and this data is within the range of $2.5 \%$ to $7.3 \%$ in the literature $(27,29,30)$.

\section{Study Limitations}

The retrospective nature of our study is an important limitation. No comparison with the Si system can also be regarded as a limitation. However, this comparative study was previously reported from our clinic (12) and the main objective of this study was to present that a fully robotic approach in rectum tumor surgery with the Xi system is possible. Considering the limited number of studies in the literature, increasing data on this subject may lead further prospective comparative studies.

\section{Conclusion}

The multiquadrant access feature provided by the Xi robot system enables multiquadrant abdominal surgery to be performed with a fully robotic approach without the need for a laparoscopic assistance, robot re-docking or re-positioning of the trocars. This feature allows the surgeon to make an optimal use of the advantages of robotic surgery in all stages of rectal cancer surgery.

Ethics Committee Approval: The study was approved by the Ethics Committee of Acıbadem Mehmet Ali Aydınlar University Hospital with the decision number 2017-12/7.

Informed Consent: Informed consent was obtained from all patients included in the study and their data were used.

Peer-review: Externally and internally peer-reviewed.

Author Contributions: Concept - V.Ö., A.D., S.A.B., E.A., B.B., I.H., T.K.; Design - V.Ö., A.D., S.A.B., E.A., B.B., İ.H., T.K..; Supervision - V.Ö., A.D., S.A.B., E.A., B.B., I.H., T.K.; Resources - V.Ö., B.B., T.K.; Data Collection and/or Processing - V.Ö., A.D., S.A.B., B.B.; Analysis and/or Interpretation V.Ö., E.A., B.B., T.K.; Literature Search - V.Ö., E.A., T.K.; Writing Manuscript - V.Ö., E.A., T.K.; Critical Review - V.Ö., A.D., S.A.B., E.A., B.B., I.H., T.K.

Conflict of Interest: The authors have no conflict of interest to declare.

Financial Disclosure: The authors declared that this study has received no financial support.

\section{References}

1. Heald RJ, Husband EM, Ryall RD. The mesorectum in rectal cancer surgery-the clue to pelvic recurrence? $\mathrm{Br}$ J Surg 1982; 69: 613-6.

2. Kapiteijn E, Marijnen CA, Nagtegaal ID, Putter H, Steup WH, Wiggers T, et al. Preoperative radiotherapy combined with total mesorectal excision for resectable rectal cancer. N Engl J Med 2001; 345: 638-46.

3. van der Pas MH, Haglind E, Cuesta MA, Fürst A, Lacy AM, Hop WC, et al; COlorectal cancer Laparoscopic or Open Resection II (COLOR II) Study Group. Laparoscopic versus open surgery for rectal cancer (COLOR II): short-term outcomes of a randomised, phase 3 trial. Lancet Oncol 2013; 14: 210-8.

4. Jayne DG, Thorpe HC, Copeland J, Quirke P, Brown JM, Guillou PJ. Five-year follow-up of the Medical Research Council CLASICC trial of laparoscopically assisted versus open surgery for colorectal cancer. Br J Surg 2010; 97: 1638-45.
5. Shearer R, Gale M, Aly OE, Aly EH. Have early postoperative complications from laparoscopic rectal cancer surgery improved over the past 20 years? Colorectal Dis 2013; 15: 1211-26.

6. Stevenson AR, Solomon MJ, Lumley JW, Hewett P, Clouston AD, Gebski VJ, et al; ALaCaRT Investigators. Effect of laparoscopic-assisted resection vs open resection on pathological outcomes in rectal cancer: The ALaCaRT randomized clinical trial. JAMA 2015; 314: 1356-63.

7. Guillou PJ, Quirke P, Thorpe H, Walker J, Jayne DG, Smith AM, et al; MRC CLASICC trial group. Short-term end points of conventional versus laparoscopic-assisted surgery in patients with colorectal cancer (MRC CLASICC trial): multicentre, randomised controlled trial. Lancet 2005; 365: 1718-26.

8. Scarpinata R, Aly EH. Does robotic rectal cancer surgery offer improved early postoperative outcomes? Dis Colon Rectum 2013; 56: 253-62.

9. Pigazzi A, Ellenhorn JD, Ballantyne GH, Paz IB. Robotic-assisted laparoscopic low anterior resection with total mesorectal excision for rectal cancer. Surg Endosc 2006; 20: 1521-5.

10. Park IJ, You YN, Schlette E, Nguyen S, Skibber JM, Rodriguez-Bigas MA, et al. Reverse-hybrid robotic mesorectal excision for rectal cancer. Dis Colon Rectum 2012; 55: 228-33.

11. Koh DC, Tsang CB, Kim SH. A new application of the four-arm standard da Vinci ${ }^{\circledR}$ surgical system: totally robotic-assisted left-sided colon or rectal resection. Surg Endosc 2011; 25: 1945-52.

12. Ozben V, Cengiz TB, Atasoy D, Bayraktar O, Aghayeva A, Erguner I, et al. Is da Vinci Xi Better than da Vinci Si in Robotic Rectal Cancer Surgery? Comparison of the 2 Generations of da Vinci Systems. Surg Laparosc Endosc Percutan Tech 2016; 26: 417-23.

13. Protyniak B, Jorden J, Farmer R. Multiquadrant robotic colorectal surgery: the da Vinci Xi vs Si comparison. J Robot Surg 2017.

14. Tamhankar AS, Jatal S, Saklani A. Total robotic radical rectal resection with da Vinci Xi system: single docking, single phase technique. Int J Med Robot 2016; 12: 642-7.

15. Morelli L, Guadagni S, Di Franco G, Palmeri M, Caprili G, D'Isidoro C, et al. Use of the new da Vinci $\mathrm{Xi}^{\circledR}$ during robotic rectal resection for cancer: a pilot matched-case comparison with the da Vinci Si ${ }^{\circledR}$. Int J Med Robot 2017; 13.

16. Harris PA, Taylor R, Thielke R, Payne J, Gonzalez N, Conde JG. Research electronic data capture (REDCap)-a metadata-driven methodology and workflow process for providing translational research informatics support. J Biomed Inform 2009; 42: 377-81.

17. D'Annibale A, Morpurgo E, Fiscon V, Trevisan P, Sovernigo G, Orsini C, et al. Robotic and laparoscopic surgery for treatment of colorectal diseases. Dis Colon Rectum 2004; 47: 2162-8.

18. Park SY, Choi GS, Park JS, Kim HJ, Ryuk JP. Short-term clinical outcome of robot-assisted intersphincteric resection for low rectal cancer: a retrospective comparison with conventional laparoscopy. Surg Endosc 2013; 27: 48-55.

19. Hellan M, Anderson C, Ellenhorn JD, Paz B, Pigazzi A. Short-term outcomes after robotic-assisted total mesorectal excision for rectal cancer. Ann Surg Oncol 2007; 14: 3168-73.

20. Baik SH, Ko YT, Kang CM, Lee WJ, Kim NK, Sohn SK, et al. Robotic tumorspecific mesorectal excision of rectal cancer: short-term outcome of a pilot randomized trial. Surg Endosc 2008; 22: 1601-8.

21. Hellan M, Stein H, Pigazzi A. Totally robotic low anterior resection with total mesorectal excision and splenic flexure mobilization. Surg Endosc 2009; 23: 447-51.

22. Choi DJ, Kim SH, Lee PJ, Kim J, Woo SU. Single-stage totally robotic dissection for rectal cancer surgery: technique and short-term outcome in 50 consecutive patients. Dis Colon Rectum 2009; 52: 1824-30. 
23. Luca F, Cenciarelli S, Valvo M, Pozzi S, Faso FL, Ravizza D, et al. Full robotic left colon and rectal cancer resection: technique and early outcome. Ann Surg Oncol 2009; 16: 1274-8.

24. Karahasanoglu T, Hamzaoglu I, Baca B, Aytac E, Erguner I, Uras C. Robotic surgery for rectal cancer: initial experience from 30 consecutive patients. J Gastrointest Surg 2012; 16: 401-7.

25. Holzmacher JL, Luka S, Aziz M, Amdur RL, Agarwal S, Obias V. The use of robotic and laparoscopic surgical stapling devices during minimally invasive colon and rectal surgery: a comparison. J Laparoendosc Adv Surg Tech A 2017; 27: $151-5$.

26. Kim JC, Lee JL, Park SH. Interpretative guidelines and possible indications for indocyanine green fluorescence imaging in robot-assisted sphincter-saving operations. Dis Colon Rectum 2017; 60: 376-84.
27. Gómez Ruiz M, Alonso Martin J, Cagigas Fernández C, Martín Parra JI, Real Noval H, Martín Rivas B, et al. Short- and mid-term outcomes of roboticassisted total mesorectal excision for the treatment of rectal cancer. Our experience after 198 consecutive cases. Eur J Surg Oncol 2016; 42: 848-54.

28. Tang B, Zhang C, Li C, Chen J, Luo H, Zeng D, et al. Robotic total mesorectal excision for rectal cancer: a series of 392 cases and mid-term outcomes from a single center in China. J Gastrointest Surg 2017; 21: 569-76.

29. Speicher PJ, Englum BR, Ganapathi AM, Nussbaum DP, Mantyh CR, Migaly J. Robotic low anterior resection for rectal cancer: a national perspective on short-term oncologic outcomes. Ann Surg 2015; 262: 1040-5.

30. Hara M, Sng K, Yoo BE, Shin JW, Lee DW, Kim SH. Robotic-assisted surgery for rectal adenocarcinoma: short-term and midterm outcomes from 200 consecutive casesat a single institution. Dis Colon Rectum 2014; 57: 570-7. 